and new kinds of connexions will establish themselves from the reformed first year. The obstacles to these later steps will be very groat. But they can scarcely be so serious as were those to this first step. A new world will be opened to the teacher, the pupil, and the university. How large a world it will be we may leave the future to discover. But it will certainly be a world which includes something of man and mankind: and it will probably be a world in which the teaching of biology has a place not far from the centre of university education.

'Darlington, C. D., Darwin's Place in History (1959).

${ }^{2}$ Ashby, E., Crew, F. A. E., Darlington, C. D., Ford, E. B., Haldane, J. B. S., Salisbury, E. J., Turrill, W. B., and Waddington, C. H., Nature, 138, 972 (1936).

${ }^{3}$ Fifteentih Ann. Rep. Adv. Counc. Sci. Policy, Cmnd. 1920 (H.M.S.O., 1961-62).

4 Catcheside, D. G., Nature, 197, 427 (1963).

5 Pringle, J. W. S., School. Sci. Rev. (in the press).

\title{
DR. MARGARET MURRAY
}

\section{TRIBUTE TO A CENTENARIAN}

$\mathrm{M}$ ARGARET ALICE MURRAY was born on July 13, 1863, in Calcutta; her parents' genoration had witnessed the Indian Mutiny, but she grew up in the Golden Age when Britain's prestige and prosperity were at their height. The child's first journey home was by way of the Cape, for the Suez Canal was not open. She remembers rolling bandages for the wounded of the Franco-Prussian War, and her compassion was early aroused by her mother's devotion to the education of the women of India. Her own was that of a young girl of her time; but, not content with a social life, she worked in a local hospital and was soon 'in charge' of a ward.

She left India for good before she was twenty-five years old, her prodigious and accurate memory stored with impressions of the life and religion of many races and creods, which were to stand her in good stead in her chosen caroor. Miss Murray was fortunate to become a student at University College in the newly formed Depart. ment of Egyptology when Sir Flinders Petrie was evolving a new science. They had to write their own text-books from direct observation, and a measure of Dr. Murray's contribution is seen in about a hundred books and articles. But more valuable still, two distinguished generations of archæologists are in her debt as a wise and witty teacher, who never forgets that her subject is the study of man, mentally and spiritually, from the time that he emerged from the animal.

Dr. Murray's excavations were carriod out mainly in Egypt, Malta, Petra, Palestine and Britain. She retired from the assistant professorship of Egyptology in University College, London, in 1935. She is also well known for her studies in folk-lore and witchcraft.

Dr. Murray follows the discoveries of the space age with as much zest as she gave to the invention of the bicycle; her delight in her particular fields of research is undimmed and distilled in her latest book The Genesis of Religion. Her autobiography, My First Hundred Years, follows this month, and if she sometimes regrets that she has led an uneventful life, this is surely an understatement

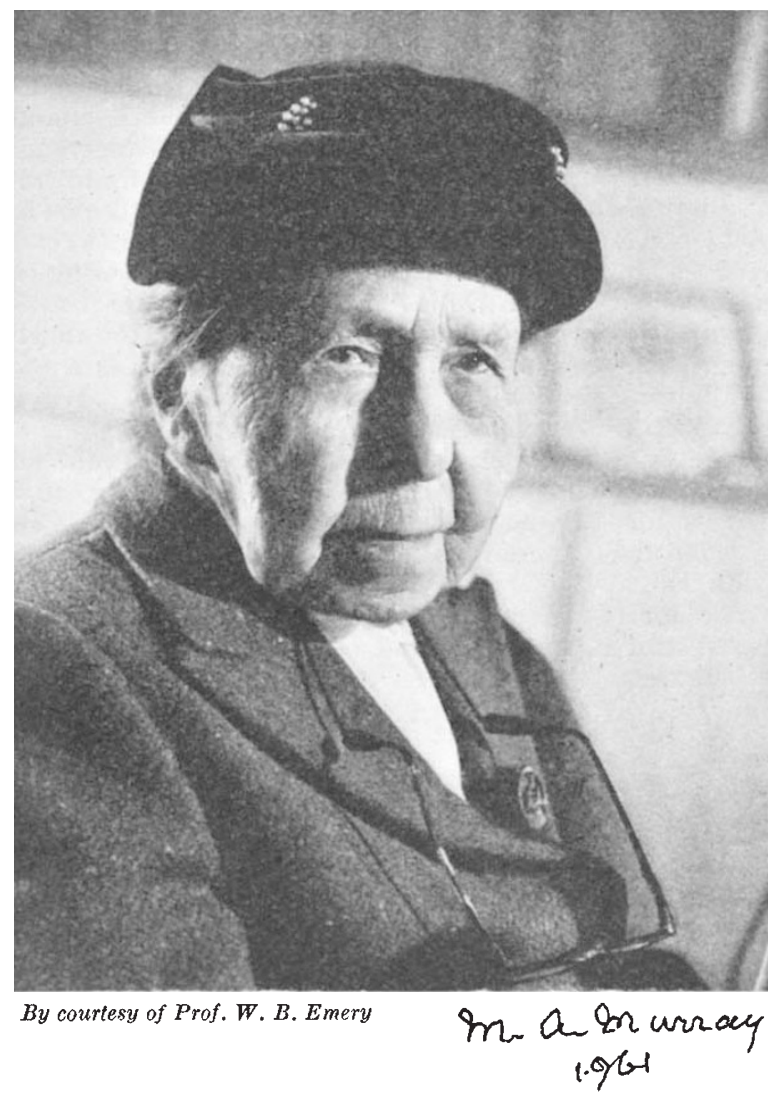

for someone who has lived gallantly through the adventure of one century and looks forward to the next.

Olga Tufneli

\section{NEWS and VIEWS}

\author{
The Royal Society of Edinburgh: Foreign Honorary \\ Fellows \\ THE following have been elected Foreign Honorary \\ Fellows of the Royal Society of Edinburgh: Prof. M. \\ Calvin, professor of chemistry, University of California, \\ Berkeley; Dr. V. A. Engelhardt, director, Institute of \\ Physico-Chemical and Radiation Biology, Moscow; Prof. \\ A. Frey-Wyssling, professor of botany, Eidgenössische \\ Technische Hochschule, Zurich; Prof. P. E. M. J. Pruvost, \\ professor of geology, Paris; Prof. S. L. Sobolev, professor \\ of mathematics, University of Moscow; Prof. W. Szafer, \\ professor of botany, Cracow; Prof. V. F. Weisskopf, \\ director-general, European Organization for Nuclear \\ Research, Geneva.
}

\section{Awards}

Dr. E. M. PAtrerson, Department of Mathematics, University of Aberdeen, has been awarded the MakdougallBrisbane Prize for the period 1960-62 for his papers on linear algebras published in the Proceedings of the Society during the period of the award and earlier papers on cognate subjects also published by the Society. Mr. K. V. Blaiklock, Kenton, Exeter, has been awarded the Dr. W. S. Bruce Memorial Prize for 1962 commemorating Dr. W. S. Bruce, the Scottish explorer and scientific investigator in polar regions, in recognition of his contributions by way of navigation to the exploration of the Antarctic Continent and for his mapping of lands bordering the Weddell Sea. 